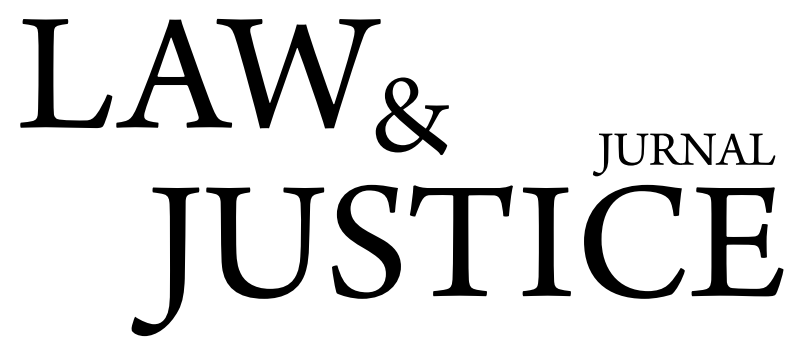

\title{
HUKUM TRANSENDENTAL DALAM PUTUSAN PENGADILAN NEGERI PURWOREJO; ANALYSIS CONTENT PUTUSAN NOMOR: 61/Pid.B/2011/PN.Pwr
}

\author{
Farkhani \\ Dosen Fakultas Syari'ah IAIN Salatiga \\ Email: farkhani_76@yahoo.com \\ Badwan \\ Dosen Fakultas Syari'ah IAIN Salatiga \\ Aesthetica Fiorini Mantika \\ Dosen Fakultas Hukum Universitas Muhammadiyah Mataram \\ Email: esti.fraydin@gamil.com
}

\begin{abstract}
Abstrak
Penelitian ini termasuk dalam kategori penelitian pustaka (library research) dengan menggunakan metode kualitatif dengan teknik pengambilan data melalui metode dokumentasi. Obyek yang diteliti adalah Putusan Pengadilan Negeri Purworejo, yang tertuang dalam Putusan Nomor: 61/Pid.B/2011/PN.Pwr., dengan menggunakan analisis kualitatif. Masalah yang dikaji adalah berkenaan dengan paradigma hukum transendental yang secara sepesifik mengkaji argumentasi hukum dalam putusan tersebut. Hasil penelitian ini menyatakan argumentasi hukum yang mengintrodusir paradigma hukum transendental khususnya dalam Putusan Nomor: 61/ Pid.B/2011/PN.Pwr, Majelis Hakim dalam hal ini terkesan; a) hanya mimilih dan memilah norma hukum transendental dari diktum kitab suci agama yang bersifat umum, enggan mengelaborasi lebih dalam dan luas terhadap diktum atau norma yang memuat sanksi hukum terhadap suatu tindak pidana (dalam hal ini pidana pembunuhan), dan b) norma hukum transendental yang digunakan sebagai argumentasi hukum belum dapat memberi warna secara signifikan terhadap putusan pengadilan, sehingga kesannya diktum dari kitab suci itu baru sekedar menjadi penambah argumentasi hukum dalam lembar-lembar putusan pengadilan.
\end{abstract}

Kata kunci: hukum transendental, norma agama, argumentasi hukum

\section{Pendahuluan}

Gerak dan wacana hukum, dalam perkembangannya terus mengalami perubahan dan pergeseran. Bermula dari kajian tentang filsafat alam yang berkembang pada zaman Yunani Kuno, kemudian dengan kehadiran Socrates, Plato dan Aristoteles filsafat yang semula hanya memperbincangkan perdebatan 
diseputar penciptaan alam kemudian bergeser pada problem keseharian hidup manusia atau situasi manusiawi (Otje Salman S, 2012: 2). Pada masa ini, alam dimana manusia itu tinggal dianggap sebagai suatu kekuasaan yang mengancam manusia. Oleh karenanya perlu ada orang yang mampu menghadapi alam sebagai sesuatu yang penuh misteri dan sakral itu dan sebab manusia itu juga hidup dalam alam, maka manusia pun dianggap sesuatu yang mengandung misteri juga (Theo Huijber, 1982: 19).

Socrates, Plato dan Aristoteles mencoba merubah paradigma masyarakakat Yunani Kuno yang religio primitif, menjadi lebih realitis dan rasionalis dengan mengajukan pertanyaan-pertanyaan mendasar tentang tujuan hidup. Ajaran yang dibawakan oleh tiga filosof guru dan murid jelas merubah alam pemikiran manusia yang sebelumnya bahwa kehidupan itu berjalan sebagai suatu keharusan alamiah saja menjadi lebih manusiawi. Bermula dari pemikiran mereka, lalu muncul pemikiran tentang hukum. Sebab pemikiran awal yang muncul adalah tentang filsafat alam, maka aliran hukum yang pertama muncul adalah aliran filsafat hukum alam, kemudian seiring perkembangan zaman muncul aliran-aliran hukum lainnya seperti positifisme, utulitarianisme, aliran hukum wahyu dan lain-lain. Diantara aliranaliran itu ada dominasi dalam penerapan hukum ada pula yang berhenti dalam tataran makna dan hanya berlaku dalam kurun waktu yang pendek kemudian berhenti dalam diskursus ilmu pengetahuan hukum.

Dari banyaknya aliran pemikiran hukum pada masa klasik sampai pada post modernisme, Stanley L. Poulsen dan Shidarta membaginya dalam dua model aliran hukum yang pembagian tersebut berangkat dari pola hubungan antara hukum, fakta dan moral; pertama hukum yang menyatu dengan fakta (reductive thesis) dan terpisah dari fakta (normativity thesis). Kedua, hukum menyatu dengan moral (morality thesis) dan terpisah dari moral (separability thesis). Dari pola ini Poulsen tidak merinci pada banyak aliran-aliran pemikiran dalam hukum, ia hanya melampirkan tiga aliran pemikiran hukum, yaitu; aliran hukum kodrat (natural law theory), aliran legisme hukum ala Kelsenian (Klesen's pure theory of law) dan aliran realisme hukum (empirico-positivist theory of law) (Shidarta dalam Absori dkk, 2017: 4).

Pada masa dasa warsa terakhir, muncul ragam tawaran pemikiran hukum baik di dalam negeri maupun di luar negeri. Di dalam negeri muncul aliran hukum progresif yang diinisiasi oleh begawan hukum dari Universitas Dipenogoro Semarang, Satjipto Raharjo, hukum non sistemik yang dipelopori oleh Anthon F. Susanto seorang dosen Fakultas Hukum Universitas Pasundan Bandung dan beberapa aliran pemikiran hukum lainnya, yang paling mutakhir, Universitas Muhammadiyah Surakarta sedang gencar menyebarkan wacana hukum transendental.

Munculnya wacana pemikiran hukum yang beyond postmodernisme di Indonesia itu tidak lain adalah bermula pada kegagalan legal positifisme hukum dalam memecahkan persoalan-persoalan kontemporer hukum yang sesungguhnya tidak an sich membutuhkan kepastian hukum dan legalitas atas segala perbuatan hukum.

Mengubah arah pemikiran hukum dari para penegak hukum di Indonesia bukan urusan semudah membelah pisang. Penancapan alur fikir legal positifisme sangat panjang, dimana awal masa munculnya pemikiran hukum legal formalisme pada tahun $1650 \mathrm{M}$, Belanda melalui VOC-nya dan pemerintahan kolonialnya. Masa tanam dan internalisasi norma dan produk hukum kolonial yang positifistik ini jelas telah mengurat akar, dan sangat sulit dihilangkan dalam sejarah perkembangan hukum di Indonesia, maka dapat saja dipahami mengapa hakim-hakim itu mayoritas terkungkung dan nyaman terjebak dalam lingkaran legal formalistik yang positifitik, rasionalistik dan empiristik (Farkhani dan Evi Aryani, 2016: 31).

Legal formalistik yang positifistik, seusungguhnya tidak begitu buruk bilamana konsistensi dalam menjalankan hukum untuk keadilan dan kepastian hukumnya diterapkan secara adil kepada siapapun, prinsip atau azas equal before the law dipegangi dengan teguh oleh seluruh penegak hukum.

Ketidakkonsistenan yang selama ini diperlihatkan membuat pesimistis terhadap sistem hukum dan peradilan selama ini. Realitas yang kasat mata mempertontonkan para penegak hukum menjadi sangat cekatan, tegas dan mantap memproses hukum pada para terdakwa dari kalangan masyarakat kaum proletar. Sementara pada kasus-kasus yang melibatkan politisi, birokrat, selebriti, penguasa dan pemilik modal, kebenaran dan keadilan hukum diperdagangkan (Farkhani dan Evi Aryani, 2016: 32). Equality before the law hanya menjadi mimpi buruk bagi para pencari keadilan hukum dari masyarakat proletar. 
Zaman terus bergerak dan berubah, norma hukum positif walaupun belum juga bergeser dari posisinya, norma adat, norma kesopanan, norma kesusilaan dan norma agama mulai lebih sering dilirik, dijadikan bahan hukum guna tercapainya keadilan hukum sedekat mungkin dengan keadilan yang sesungguhnya. Terkhusus dengan norma agama, hakim yang hidup dalam negara Indonesia yang berke-Tuhan-an Yang Maha Esa dan dalam setiap irah-irah putusannya tercantum "Demi Keadilan yang berdasarkan Ketuhanan Yang Maha Esa", menjadikan hakim sebagai "wakil" Tuhan di muka bumi untuk penegakan keadilan bagi seluruh manusia.

Dalam sejarah putusan pengadilan di Indonesia, sungguh telah ada hakim yang memiliki pemikiran bahwa hakim adalah "wakil" Tuhan. Nama Bismar Siregar (dalam posisi sebagai judex facti) menjadi rujukan utama sebagai salah satu hakim yang paling sering menggunakan argumentasi yang berlandaskan norma-norma agama dalam setiap putusannya. Setelah era Bismar Siregar, sulit didapatkan hakim yang menggunakan norma agama menjadi salah satu argumentasi dalam memutuskan perkara dalam persidangan. Akhir-akhir ini muncul putusan hukum yang semisal dengan apa yang pernah dilakukan oleh Bismar Siregar. Dalam sebuah persidangan pada perkara pembunuhan berencana di Pengadilan Negeri Purworejo, majlis hakim yang diketuai oleh Purnawan Narsongko, S.H., dengan hakim anggota Alex. TMH. Pasaribu, S.H. dan Mardiana Sari, S.H., M.H., menggunakan norma-norma agama sebagai salah satu argumentasi pemberian hukuman pada terdakwa Adriawan bin Subarjo.

Tulisan ini mengkaji putusan hukum hakim Pengadilan Negeri Purworejo dalam menggunakan norma agama sebagai argumen hukum untuk pemberian hukuman pada terdakwa, dan bertolak dari persoalan ini juga akankah semakin terbuka dan berani para penegak hukum untuk menggunakan norma hukum transendental sebagai norma hukum yang keberlakuannya diakui secara terbuka dan menasional.

\section{Hukum transendental sebagai Argumentasi Hukum dalam Putusan Pengadilan}

Transendental, dalam bahasa Inggris 'transcendent', berasal dari bahasa Latin 'trancender'. Trans bermakna seberang, atas, melampaui dan scender bermakna memanjat. Dari arti bahasa ini, muncul beberapa pengertian tentang makna istilah dari transendental; 1) sesuatu yang lebih tinggi, unggul, agung, melampaui, superlatif, 2) melampaui apa yang dalam pengalaman, 3) berhubungan dengan apa yang selamanya melampaui pemahaman terhadap pengalaman biasa dan penjelasan ilmiah, 4) tidak tergantung dan sendiri.

Dari penjelasan awal muncul wacana transendentalia pada abad pertengahan, dapat dipahami bahwa yang dimaksud dengan transendental adalah sesuatu yang berada di luar batas kemampuan dan pengalaman-pengalaman yang berawal dari eksploitasi ruang rasio dan inderawi manusia, ia adalah sesuatu yang tinggi, agung, suci, dan unggul, metafisis dan sangat mungkin bersifat ilahiyah.

Bila pengertian ini diterapkan pada ranah hukum, disebut sebagai hukum transendantal, secara sederhana adalah hukum yang tidak hanya terpaku pada produk-produk hukum yang argumentasi dan tafsirnya yang terpancang pada segala apa yang dapat ditangkap oleh logika hukum yang rasionalistik empiristik, tetapi melampaui batas-batas itu yang bersifat metafisis dan ilahiyah. Sebab dalam ranah hukum, produk hukum akan selalu terkait dengan sumber hukumnya dan idea of law, maka jalur yang paling singkat dan mudah untuk menemukan dan memahaminya adalah dalam norma-norma agama yang tersimpan rapih dalam diktum-diktum ajaran agama dalam masing-masing kitab suci agama. Selanjutnya lebih mudah menyebutnya sebagai norma dan/atau nilai agama. Singkatnya hukum transendental adalah objektifikasi norma dan/atau nilai agama menjadi hukum bagi manusia.

Dari perkembangan tawaran aliran hukum transendental ini, terus disebarkan kepada para pemegang kepentingan atas tegaknya hukum yang sering kali terlihat semakin tidak menentu arahnya, sering meleset dari rel keadilan dan jauh dari rasa keadilan masyarakat.

Upaya-upaya untuk pembenahan untuk terciptanya hukum yang ideal terus diupayakan, termasuk merubah mainset para penegak hukum dan menggunakan argumentasi hukum yang sebelumnya sangat terkotak dalam idealita positivisme hukum. Terutama paradigma pemikiran hukum para hakim sebagai benteng keadilan hukum yang terakhir. Putusan-putusan pengadilan yang merupakan hasil karya pemikiran para hakim, selama ini mayoritas didominasi pola pemikiran positivistik. Argumentasinya 
lebih sering tertuju lebih banyak berlandaskan kitab-kitab hukum (law in book law), sangat jarang mencari argumentasi hukum berdasarkan pada norma-norma lain yang hidup dan diakui dalam sistem hukum di Indonesia.

Andaipun ada, ujung-ujungnya hukum atau sanksi yang diterapkan kembali lagi pada peraturan perundangan yang sudah ada, sangat jarang yang hasil akhirnya out of the box dari positivisme.

Berkenaan dengan argumentasi hukum yang dapat saja dipakai oleh siapa saja yang memiliki perkara atau kepentingan yang berkaitan dengan hukum. Argumentasi hukum menjadi wajib untuk dikemukakan agar pihak lain memahami persoalan yang sedang diperbincangkan atau dihadapi.

Berbicara dan menggunakan argumentasi hukum dalam praktik, tidak bisa dipisahkan dengan penalaran (logika) hukum dan penafsiran (interpretasi) hukum. Penalaran (logika) secara terminologi adalah suatu metode yang penilaian terhadap ketepatan penalaran yang dipakai untuk suatu argumentasi, sedangkan teori argumentasi ialah cara untuk mengkaji bagaimana menganalisis dan merumuskan suatu argumentasi (secara tepat dan jelas), serta rasional yang kemudian diimplementasikan dengan cara mengembangkan kriteria universal dan/atau kriteria yuridis sebagai suatu landasan rasional argumentasi hukum (Feteris, E.T., 1994: 2).

Penalaran (logika) hukum yang diajukan dapat benar dan dapat pula sesat. Benar, apabila ada korelasi logis antara premis dan konklusi dan sesat, bila tidak ada korelasi logis antara premis dan konklusi. Oleh sebab itu nalar yang baik dan benar perlu dilatih dengan berbagai metode hingga ia menjadi sebuah keterampilan yang inhern pada pola pikir seseorang. Peran nalar yang baik dan benar, runut dan argumentatif sangat penting perannya dalam memberikan argumentasi hukum.

Adapun interpretasi hukum lebih merupakan suatu teknik untuk memahami norma hukum (peraturan perundangan)agar dapat menangkap pesan yang hendak dicapai oleh norma yang ada. Karena hukum dalam bentuk peraturan perundang-undangan adalah buah karya manusia dan merupakan produk politik yang sarat akan kepentingan. Walaupun kodifikasi tersebut telah diupayakan dengan sungguh-sungguh detail-detailnya tetap saja tidak akan sempurna, tetap menyisakan celah yang dapat dimanfaatkan oleh siapa saja agar terhindar dari jerat hukum. Apalagi akselerasi dinamika perubahan dan kemajuan kehidupan manusia selalu lebih cepat daripada hukum yang terkodifikasi tersebut. Oleh sebab itu muncul model-model penafsiran (interpretasi) hukum, kodifikasi hanya berfungsi sebagai pedoman agar ada kepastian hukum. Jangankan hukum yang diproduk manusia, hukum yang diturunkan Tuhan melalui kitab suci nabi-nabi-Nya ternyata memunculkan pula metode-metode penafsiran.

Bertalian dengan penafsiran hukum tersebut, Wirjono Prodjodikoro menegaskan bahwa segala hukum baik yang tertulis yang termuat dalam pelbagai undang-undang, maupun yang tidak tertulis, yaitu berdasar atas adat kebiasaan seperti hukum adat, selalu membuka kemungkinan ditafsirkan secara bermacam-macam. Tergantung dari tafsiran inilah sebetulnya bagaimana isi dan maksud sebenarnya dari suatu peraturan hukum harus dianggap. Kalau diingat, bahwa pada akhirnya penafsiran dari hakimlah yang mengikat kedua belah pihak, maka dapat dikatakan bahwa hakim adalah perumus dari hukum yang berlaku. Dengan demikian pekerjaan hakim mendekati sekali pekerjaan pembuat undang-undang selaku pencipta hukum (judge made law) (Farkhani, 2014: 97-98).

Interpretasi hukum hasil akhirnya adalah temuan hukum. Namun demikian, norma hukum tidak dapat diinterpretasikan bila tidak menggunakan alat yang disebut nalar hukum sebagaimana diterangkan di atas.

Irah-irah putusan yang berbunyi "demi keadilan yang berdasarkan Ketuhanan Yang Maha Esa" dan statemen Hakim Agung Inggris Lord Denning menunjukkan bahwa hakim tidak boleh lepas dari spirit transendental dalam memutuskan setiap perkara. Transendensi, menurut Kontowijoyo (2006: 98) secara singkat dijelaskan sebagai implementasi keimanan kepada Tuhan, dalam Islam dibahasakan sebagai tu'minuna billah (QS. Ali Imran: 110). Atau dapat pula diperlebar bahwa transendensi adalah menempatkan nilai nilai agama pada kedudukan yang sentral dan tinggi dalam ragam ilmu. Dalam ranah hukum dapat dimaknai bahwa hukum transendental berisi nilai-nilai suci agama yang diimplementaskan dalam produk hukum, termasuk didalamnya putusan pengadilan yang dibuat oleh hakim. 
Pemikiran ini merupakan reaksi atas ekses-ekses negatif yang ditimbulkan oleh modernisasi dalam bidang ilmu sosial khusunya (hukum) sehingga mendorong terjadinya gairah untuk menangkap kembali alternatif-alternatif yang ditawarkan oleh agama untuk menyelesaikan persoalan-persoalan kemanusiaan. Dalam bingkai modernisasi yang selama ini berlangsung menempatkan menempatkan manusia sebagai produk renaissance yang berakar pada rasio manusia. Pusaran antroposentrisme menjadikan manusia sebagai pusat dunia, manusia merasa cukup dengan dirinya sendiri dan melepaskan diri dari nilai-nilai di luar dirinya (sekularisasi). Dari proyek ini selanjutnya adalah menempatkan rasio manusia di atas segalanya, manusia memproklamirkan dirinya sebagai penguasa diri dan alam raya. Kesombongan rasio ini pada akhirnya manusia menjalani kehidupannya tanpa makna, termasuk pada setiap produk yang dihasilkan dari rasionya. Rasionalisasi miskin transendensi, miskin transendensi berati miskin makna, mengesampingkan moralitas, terperangkap dalam penjara yang tertangkap indera.

Nilai-nilai transendensi yang diadopsi dalam dunia hukum akan menjadi dasar dari humanisasi dan liberasi manusia yang menjadi subyek hukum. Transendensi hukum (hukum transendental) diharapkan akan memberi arah kemana dan untuk tujuan apa humanisasi dan liberasi itu dilakukan. Transendensi hukum di samping berfungsi sebagai dasar nilai bagi praksis humanisasi dan liberasi, juga berfungsi sebagai kritik. Dengan kritik transendensi, kemajuan teknik dapat diarahkan untuk mengabdi pada perkembangan manusia dan kemanusiaan, bukan pada kehancurannya.

Dalam putusan hakim, dikenal istilah legal reasoning. Pengertian legal reasoning digunakan dalam dua arti, yaitu dalam arti luas dan sempit. Dalam arti luas, legal reasoning berkaitan dengan proses psikologi yang dilakukan Hakim, untuk sampai pada keputusan atas kasus yang dihadapinya. Studi legal reasoning dalam arti luas menyangkut aspek psikologi dan aspek biographi. Legal reasoning dalam arti sempit, berkaitan dengan argumentasi yang melandasi satu keputusan. (Golding, 1984: 1).

Legal reasoning atau argumentasi hukum keberadaannya adalah wajib dalam setiap putusan pengadilan. Karena tidak mungin seorang hakim atau juris pada umumnya, menghadapi persoalan hukum dalam ruang hampa, pasti ada pijakan-pijakan yang akan dipilih untuk menyusun logika argumentatif, menyesuaikan antara teks dengan konteks. Hakim harus bertanggung jawab atas penetapan dan putusan yang dibuatnya serta di dalam membuat pertimbangan hukum hakim harus berdasarkan pada alasan dan dasar hukum yang tepat dan benar (pasal 68 A UU No. 49 Tahun 2009). Pada prakteknya, hakim lebih sering berargumentasi hukum dengan hukum positif dengan simplikasi lebih terjamin kepastian hukumnya.

Realita yang demikian walaupun mayoritas tidak berarti harus diikuti untuk semua perkara hukum. Karena banyak juga kegagalan-kegagalan yang ditimbulkan yang semata-mata mengacu pada hukum positif sementara fakta tidak mesti sama persis dengan apa yang diinginkan oleh hukum positif.

Marni Emmy Mustafa (www.pt-bandung.go.id) menegaskan bahwa kepastian hukum tidak selalu menghasilkan keadilan. Mendiskusikan kepastian hukum dalam bentuk "pro-contra" adalah tidak ada manfaatnya. Kepastian hukum mungkin saja berguna untuk memastikan seberapa jauh nilai yang dapat diberikan terhadap kepastian hukum dalam kasus tertentu, sebagaimana dihadapkan pada pertimbanganpertimbangan lain yang melemahkan nilai kepastian hukum. Argumentasi untuk kepastian hukum dalam kasus yang berbeda satu sama lain akan beragam sesuai dengan ukuran yang pada gilirannya akan berubah-ubah sesuai waktu dan tempat terjadinya kasus tersebut. Berbagai alasan yuridis yang berbeda-beda akan dipergunakan atau berbagai macam metoda penemuan hukum akan diterapkan, agar di samping kepastian hukum, putusan akhir pengadilan juga akan dilandaskan pada pertimbangan akan keadilan.

Oleh karenanya yang perlu diperhatikan oleh hakim adalah kesesuaian antara fakta dengan norma, norma yang dimaksud tidak hanya berhenti pada norma hukum saja akan tetapi dapat juga mempertimbangkan norma moral, doktrin bahkan norma agama yang transendental dan bersumber pada kitab suci agama. Pada posisi seperti ini, hakim memainkan posisi kunci dalam penggunaan norma yang akan dijadikan sebagai pertimbangan atau argumentasi hukum. Bahkan sangat mungkin apa yang dilakukan oleh hakim akan lebih berarti dibandingkan dengan sekedar membunyikan undang-undang atau peraturang perundangan lainnya. Franken menegaskan bahwa pembentukan pembentukan hukum oleh hakim dianggap sebagai suatu hal yang baik karena hakim melakukan perumusan aturan-aturan 
sedemikian rupa sehingga melalui perumusan tersebut juga ditetapkan fakta yang dalam hal ini adalah fakta hukum hasil pemeriksaan mana dalam kasus tertentu menjadi relevan dan kemudian putusan akhir akan mengalir darinya sebagai satu cara penyelesaian konkret dari sengketa (Herlien Budiono, 2006: 267).

Berlandaskan pada pemaparan dimuka dan didukung oleh Undang-Undang No. 48 tahun 2009 tentang Kekuasaan Kehakiman dan Undang-Undang No. 49 tahun 2009 tentang Peradilan Umum, penggunaan agrgumentasi hukum yang bersifat transendental sungguh sangat terbuka bagi hakim untuk semua level. Hingga seharusnya mendorong untuk lahir hakim-hakim semacam Bismar Siregar yang dikenal sangat kental argumentasi hukum transendentalnya dalam setiap putusan yang dibuatnya.

\section{Analisis Paradigma Berfikir Hukum Hakim Pengadilan Negeri Purworejo dalam Putusan Nomor: 61/Pid.B/2011/PN.Pwr.}

Hukum tidak hadir dalam ruang hampa. Paling tidak anggapan secara sosiologis membenarkan premis ini, sebab hukum tidak akan mungkin berdaya guna apapun bila ia tidak hadir dalam komunitas masyarakat dan memiliki keterkaitan dengan indivudu atau entitas tertentu yang memiliki kewenangan untuk mendayagunakan hukum itu. Sebagai contoh untuk memperkuat premis tersebut adalah kehadiran hukum Islam yang bersumber pada kitab suci al-Qur'an, walaupun ia ciptaan Tuhan tetapi Tuhan tidak menafikan bahwa hukum itu diperuntukan bagi manusia, sehingga ia tidak menutup sama sekali terhadap budi, daya dan karsa yang ada pada manusia. Abdullah Ahmed al-Na'im (2001: 214) mengatakan: “....(hukum, pen) Islam tidak memulai dari lembaran putih karena ia tidak hadir dalam ruang hampa keagamaan, ekonomi, sosial dan politik...Islam merupakan kelanjutan dan kulminasi tradisi Ibrahimi. Selain itu hukum Islam dalam syari' ah menerima dan memodifikasi banyak aspek adat dan praktik Arab pra-Islam".

Dari sisi hakim sebagai pejabat negara yang menjalankan fungsi kekuasaan yudikatif dijamin oleh undang-undang untuk bebas dan mandiri dalam mengambil putusan, termasuk dalam menyampaikan secara tertulis dan lisan argumentasi yang digunakannya. Dari sisi hakim sebagai manusia biasa yang ada keterbatasan di dalam pribadinya tidak akan dapat terlepas dart berbagai faktor yang mempengaruhinya. Dalam menjalankan funggsinya hakim tidak dapat bekerja sendiri. Hakim tidak dapat terlepas dart organisasi peradilan, institusi lain termasuk dengan terdakwa maupun masyarakat. Hakim bebas dari korektifa dan rekomendasi baik dari eksekutif maupun pihak lain. Kebebasan dan kemandirian ini segalanya tergantung pada pribadi hakim. Namun yang perlu diingat adalah bahwa ketika putusan itu telah dibacakan dimuka sidang, maka putusan itu telah menjadi milik publik. Mulai saat itulah putusan hakim dapat dieksaminasi oleh siapapun untuk mengukur seberapa profesionalnya ia, kapabilitas dan integritasnya, termasuk dari sisi prosedur.

Berawal dari sinilah putusan pengadilan yang dibuat oleh hakim dapat dianalisis pada konten putusan yang telah ia buat yang berarti pula dapat dilihat paradigma berfikir hukum dari para hakim dalam mejelis hakim yang menyidangkan suatu perkara.

Harus dipahami bahwa tugas hakim sungguh berat, terutama pada saat akan mengambil putusan hukuman apa dan berapa lama atau berapa banyak denda yang harus dibanyar, atau dalam menentukan kedudukan hukum pada subyek hukum.

Putusan dalam ranah keilmuan hukum dianggap sebagai karya ilmiah yang bisa saja dieksaminasi oleh pemerhati hukum (khalayak) dan teman sejawat. Ketepatan hukum yang diambil akan mendatangkan keadilan dan menenangkan rasa keadilan masyarakat, kesalahannya akan mendatangkan caci maki dan sidang kode etik yang dapat saja berakibat pada karir hakim terhenti. Tidak hanya itu, irah-irah "demi keadilan berdasarkan Ketuhanan Yang Maha Esa", menuntut hakim tidak hanya benar di hadapan manusia tapi benar pula di hadapan Tuhan Yang Maha Pengadil. Artinya putusan yang hakim jatuhkan akan dipertimbangkan pula di akherat kelak. Bagi hakim yang beragama, beban ini bukan beban yang ringan, membawa tekanan tersendiri.

Dalam pandangan Hakim Agung Amerika Serikat, Oliver Wendell Holmes Jr., tugas hakim sebagai pemutus perkara, bahwa memutus bukan semata-mata proses silogisme matematis dan mekanis, namun sebuah makna yang sangat luas "... the life of the law has not been logic; it is has been experience. 
The felt necessities of the time, the prevalent moral and political theories, institution of public policy avowed or unconscious, even the prejudices which judges share with their fellow ...." Holmes juga mengatakan, "The law embodies the story of a nation's development through many centuries, and it can not be dealt with as if it contained only the axioms and corollaries of a book of mathematics". Dengan demikian putusan hakim merupakan cermin dari sikap, moralitas, penalaran dan banyak hal lainnya yang digambarkan oleh Holmes sebagai pengalaman. Hal itu mengisyaratkan bahwa putusan hakim akan sangat berwatak relativisme kultural, atau dengan mengambil pandangan Tamanaha tentang "mirror thesis" maka putusan merefleksikan seperti cermin dari si pemutusnya" (Komisi Yudisial, 2014: 7-8).

Sekalipun tugas hakim sangat berat, hakim tetaplah seorang manusia biasa yaitu makhluk biologis, yang memiliki juga hak psikologis yaitu untuk menjadi takut, berani, jujur, khilaf, dan lainnya. Fakta sosiologisnya, tipologi hakim bermacam-macam, tak ada satu model hakim yang menjadi model untuk penyeragaman karena hakim adalah manusia, yang hanya bisa disergamkan dalam toga dan prosedur beracara, pada titik ini kita dapat melihat hakim tidak hanya sebagai seorang birokrat hukum semata (Abraham S. Blumberg, 1970), namun juga sebagai manusia, yang terdiri dari berbagai variabel yang dapat melekat pada seorang hakim, seperti usia, latar belakang sosial, ras atau etnis, agama, pendidikan, pengalaman, dan lain-lain yang keseluruhannya memiliki peluang untuk turut menentukan bagaimana kecenderungan seorang hakim untuk memutus (Komisi Yudisial, 2014: 9). Berkenaan dengan tipologi hakim dalam memutus perkara, Satjipto Rahardjo (2003: 225) berpendapat paling tidak ada dua tipe hakim. Pertama, hakim yang apabila memeriksa, terlebih dahulu menanyakan hati-nuraninya atau mendengarkan putusan hati nuraninya dan kemudian mencari pasal-pasal dalam peraturan untuk mendukung putusan tersebut. Kedua, hakim yang apabila memutus terlebih dahulu berkonsultasi dengan kepentingan perutnya dan kemudian mencari pasal-pasal utuk memberikan legitimasi terhadap putusan perutnya.

Dalam ilmu Manajemen Kepemimpinan, Siagian (1991) menyatakan bahwa ada aspek-aspek tertentu bersifat internal dan eksternal yang dapat mempengaruhi proses pengambilan keputusan (berlaku pla bagi hakim). Adapun aspek internal tersebut antara lain :

a. Pengetahuan

Pengetahuan yang dimiliki oleh seseorang secara langsung maupun tidak langsung akan berpengaruh terhadap pengambilan keputusan. Biasanya semakin luas pengetahuan seseorang semakin mempermudah pengambilan keputusan.

b. Aspek kepribadian

Aspek kepribadian ini tidak nampak oleh mata tetapi besar peranannya bagi pengambilan keputusan.

Aspek eksternal dalam pengambilan keputusan, antara lain :

a. Kultur

Kultur yang dianut oleh individu bagaikan kerangka bagi perbuatan individu. Hal ini berpengaruh terhadap proses pengambilan keputusan.

b. Orang lain

Orang lain dalam hal ini menunjuk pada bagaimana individu melihatcontoh atau cara orang lain (terutama orang dekat) dalam melakukan pengambilan keputusan. Sedikit banyak perilaku orang lain dalam mengambil keputusan pada gilirannya juga berpengaruh pada perilkau individu dalam mengambil keputusan.

Arroba (1998) menyatakan ada beberapa hal yang dapat mempengaruhi pengambilan keputusan yang dilakukan oleh seseorang, antara lain: 1) Informasi yang diketahui perihal permasalahan yang dihadapi, 2) Tingkat pendidikan, 3) Personality, 4. Coping, dalam hal ini dapat berupa pengalaman hidup yang terkait dengan permasalahan (proses adaptasi), dan 5. Kultur.

Dilihat dari berbagai hal yang telah dibahas sebelumnya, sekali lagi bahwa putusan hakim atau putusan pengadilan apabila telah ditulis dan dibacakan dimuka sidang, setelahnya menjadi hak publik 
untuk dapat mengaksesnya, termasuk pada Putusan Pengadilan Negeri Purworejo, dalam hal ini Putusan Nomor: 61/Pid.B/2011/PN.Pwr.

Dalam Putusan Nomor: 61/Pid.B/2011/PN.Pwr., Majelis Hakim yang terlibat dalam pembuatan putusan tersebut adalah Alex T.M.H. Pasaribu, S.H., Mardiana Sari, S.H., M.H., sebagai Hakim Anggota dan Purnawan Narsongko, S.H., sebagai Hakim Ketua. Dari identitas agama dari majlis hakim, satu orang beragama katolik dan dua orang beragama Islam. Walaupun hanya ada dua agama yang dianut oleh majlis hakim, ternyata 3 (tiga) kitab suci agama besar di Indonesia diintrodusir sebagai argumentasi hukum untuk memperkuat pemberian hukuman bagi terdakwa.

Alex T.M.H. Pasaribu, S.H. yang beragama Katolik rupanya paham betul bahan kejahatan pembunuhan di larang dalam agama yang dianutnya (bible). Dalam iman Kristen pembunuhan adalah perbuatan yang dilarang. Majelis Hakim mengutip Kitab Keluaran 20:13 dan Injil Mateus 5: 21 yang berbunyi : "jangan membunuh; siapa yang membunuh harus dihukum."

Sesungguhnya tidak hanya satu ayat yang berbicara tentang pembunuhan, karena ditelisik pada bibel ada banyak ayat yang berbicara tentang pidana pembunuhan, hanya saja yang paling umum dan tidak menunjuk secara jelas hukuman apa yang akan dijatuhkan pada pelaku kejahatan pembunuhan, diktum itulah yang paling mewakili.

Sementara itu ayat-ayat yang membahas tentang pidana pembunuhan dengan jenis hukuman yang lebih jelas diantaranya; dalam kitab Kejadian 9: 6 sangat jelas berkata: "Siapa yang menumpahkan darah manusia, darahnya akan tertumpah oleh manusia, sebab Allah membuat manusia itu menurut gambar-Nya sendiri." Dalam Bilangan 35: 16 disebutkan "Jika ia membunuh seseorang dengan senjata besi, ia adalah pembunuh, dan ia harus mati".

Dalam firman kelima Perjanjian Lama melarang merampas kehidupan dengan sengaja, dari seseorang yang tidak bersalah dan yang tidak memberi perlawanan: "Jika seseorang memukul orang dengan benda besi (atau dengan sebuah batu atau dengan benda kayu) supaya mati dan orang itu mati, maka ia adalah seorang pembunuh. Pembunuh itu akan dimatikan" (Bil 35: 16-18). Bahkan dikatakan: "jika ia dengan rasa permusuhan memukul dia dengan tangannya, dan orang itu mati, maka ia adalah seorang pembunuh; penebus (goel) darah harus mematikan pembunuh itu"

Penyajian ayat-ayat tentang pembunuhan dalam Bibel di atas adalah sebagian kecil saja dari banyak ayat yang berbicara tentang pembunuhan dan balasan (hukuman) yang harus diberikan pada pembunuh. Oleh karenanya, secara garis besar dapat disimpulkan bahwa menurut Bibel (Injil) pembunuh dihukum bunuh pula.

Dari temuan banyaknya ayat yang berbicara tentang pembunuhan dan sanksi hukumnya, kemudian dibandingkan dengan argmentasi Mejelis Hakim yang salah satu diantara anggota Majelis Hakim itu beragama Katolik dengan Bibel sebagai kitab sucinya, menunjukan kurang mendalamnya Majelis Hakim dalam menggali norma (hukum) transendental yang terkandung dalam kitab suci Injil.

Selain mengutip salah satu ayat dalam bibel, Mejelis Hakim juga mengutip norma yang ada dalam agama Hindu argumentasi hukum dalam putusannya, -padahal dalam Majelis Hakim itu tidak ada satupun yang beragama Hindu, tepatnya dari kitab suci Weda yaitu Atharvaveda X: 1: 29, bahwa: "Jangan pernah membantai orang tidak bersalah, pembunuh orang yang tidak bersalah berkesudahan di dalam malapetaka, jangan membunuh manusia dan binatang bermanfaat." Serta dalam Kitab Sarasamusccaya pada Cloka 141 disebutkan: “...Sekali-kali tidak pernah menyakiti mahluk lain, tidak mengikatnya, tidak membunuhnya...".

Dalam argumentasi berlandaskan norma transendental agama Hindu, Majelis Hakim hanya menampilkan satu norma tentang larangan membunuh, dengan tidak menampilkan melandaskan argumentasi pada norma yang memuat tentang sanksi yang harus ditanggung. Padahal perbuatan membunuh manusia di dalam ajaran Hindu dikategorikan sebagai perbuatan kejam dengan sebutan sad atatayi dalam Kitab Perundangan Majapahit disebut kejahatan astadusta. Dalam Kitab Slokantara, 71: 32 dijelaskan "Orang yang membakar rumah, suka meracuni, dukun jahat, pembunuh, pemerkosa perempuan, penghianat, keenam ini dimasukan dalam golongan "Atatayi". Karena kategorisasi kejahatan yang kejam, dalam kitab Hindu lainnya, sanksi membunuh adalah dibunuh sebagai karma (balasan) atas perbuatannya sekaligus sebagai penghapus dosa “... orang-orang yang telah melakukan 
pidana dan telah pula dihukum oleh raja akan pergi ke surga karena telah bersih seperti halnya mereka yang telah melakukan perbuatan yang bajik (Manawa Dharmasastra VIII.318).

Pada argumentasi yang berasal dari kitab suci agama Hindu juga, hakim tidak begitu maksimal untuk menggali dan menemukan norma transendental Hinduisme untuk perkara pembunuhan. Sekali lagi Majelis Hakim hanya mengambil norma yang bersifat sangat umum. Ajaran tentang Karma, yang bisa saja dikaitkan dalam peristiwa pembunuhan dalam kasus ini seharusnya disampaikan sebagai argumentasi hukum guna menunjukkan kepada terdakwa dan khalayak bahwa pembunuhan apapun yang dilakukan oleh umat Hindu akan berakibat yang sama padanya, hanya persoalan waktu, tempat dan cara saja si pembenuh akan menerima karma matinya yang serupa di kemudian hari sebagaimana ia melakukan hal yang sama kepada orang lain yang telah dibunuhnya.

Argumentasi hukum yang berasal dari norma transendental hukum Islam adalah dengan memberikan penjelasan bahwa Islam adalah agama damai dan perbuatan penghilangan nyawa tanpa hak adalah perbuatan yang dilarang dalam Islam. Majelis Hakim mengutip al-Qur'an Surah Al-Isra 17:33 "Dan janganlah kamu membunuh orang yang diharamkan Allah (membunuhnya), kecuali dengan suatu (alasan) yang benar. Dan barangsiapa dibunuh secara zalim, maka sungguh kami telah memberi kekuasaan kepada walinya, tetapi janganlah walinya itu melampaui batas dalam pembunuhan. Sesungguhnya dia adalah orang yang mendapat pertolongan". Selain itu Majelis Hakim juga menerangkan bahwa perbuatan terdakwa yang telah melakukan pembunuhan kepada para korban sehingga apabila terdakwa menyesali akan perbuatan yang telah dilakukannya maka pintu ampunan terbuka bagi orang yang bertobat dimana menurut pandangan agama Islam terhadap dosa yang dilakukan umat manusia termaktub dalam al-Qur'an al-Karim sebagai berikut :

a. "Dan barang siapa mengerjakan kejahatan dan menganiaya dirinya, kemudian ia memohon ampun kepada Allah, niscaya dia mendapati Allah Maha Pengampun lagi Penyayang”. (QS. AlNisa, 4: 110);

b. "Dan Allah tidak akan mengazab mereka, sedang engkau berada diantara mereka. Dan tidak (pula) Allah akan mengazab mereka, sedang mereka memohon ampun”. (QS. Al-Anfal, 8: 33) kemudian "Dan (juga) orang - orang yang bila berbuat keji atau zalim terhadap dirinya, mereka ingat kepada Allah, lalu mereka memohon ampun atas dosa-dosanya. Dan siapa lagi yang dapat mengampunkan dosa melainkan Allah? Dan mereka tidak meneruskan perbuatan keji itu, sedang mereka mengetahui”. (QS. Ali Imran, 3: 135).

Selain mengutip beberapa ayat al-Qur'an, Majelis Hakim juga mengutip hadits yang menerangkan tentang pertaubatan manusia dari segala perbuatan dosa, yaitu hadits riwayat Turmudzi buku "Riyadhus Shalihin", Anas r.a. telah meriwayatkan sebagai berikut:

\begin{abstract}
"Saya mendengar Rasulullah Saw. bersabda: "Allah Ta'ala berfirman: "Wahai Anak Adam selama kamu berdoa dan mengharap kepadaku niscaya Aku ampuni dosa yang telah kamu lakukan dan aku tidak memperdulikan berapa banyaknya. Wahai Anak Adam, seandainya dosa - dosamu bagaikan awan di langit, kemudian kamu minta ampun kepada-Ku niscaya Aku mengampunimu, dan Aku tidak memperdulikan berapa banyak dosamu. Wahai anak Adam, seandainya kamu datang kehadapan-Ku dengan membawa dosa seisi bumi, kemudian bertemu dengan AKU tanpa menyekutukan sesuatu apapun dengan-KU, niscaya AKU akan mengampuni dosa yang seisi bumi itu."
\end{abstract}

Setelah mengutip beberapa ayat dan hadits, kemudian Majelis Hakim menambahkan pandangannya terhadap perbuatan pembunuhan itu dengan argumentasi sebagai berikut:

“ Berdasarkan pandangan terhadap sesuatu dosa yang diperbuat umat manusia, yaitu sesuai wahyu Allah dalam al-Qur'an dan Hadits Nabi Muhammad Saw. sebagaimana dikemukakan di atas, maka dapat dikonklusikan menurut ajaran agama Islam bahwa pintu ampunan atas tobat umat manusia adalah mutlak milik Allah dan merupakan rahasia Allah, bahwa bagi hamba Tuhan, 
yaitu mahluk manusia yang telah melakukan perbuatan dosa, baik berupa dosa besar berupa perbuatan keji maupun dosa kecil, maka pintu tobat dan ampunan masih terbuka dihadapan Allah dengan syarat si hamba atau manusia itu sendiri dengan sungguh-sungguh bertawaduk dan menghadap kepada Allah Swt. untuk tidak mengulangi perbuatannya, serta tidak menyekutukan Allah kepada selain Allah, juga si hamba atau manusia tersebut dengan penyerahan diri secara mutlak berupa kepasrahan hati yang mutlak kepada Allah dan melaksanakan seluruh perintah Allah serta menjauhi segala larangan-Nya".

Mendasarkan pada kitab suci al-Qur'an sebagai argumentasi hukum transendentalnya, berbeda ketika merujuk pada dua kitab sebelumnya (Injil dan Weda). Ayaut suci al-Qur'an yang dikutip oleh Mejelis Hakim memberikan petunjuk yang jelas bahwa sanksi hukum jarimah pembunuhan adalah dibunuh, dalam bahasa al-Qur'an yang lainnya disebut qishash.

Dalam hal argumentasi hukum ini, 2 (dua) orang hakim yang beragama Islam juga tidak melakukan pengkajian yang layak, seperti mencoba mengkaji delik pembunuhan dalam perspektif Fiqh Jinayah. Pengkajian terhadap jarimah pembunuhan dalam perspektif Fiqh Jinayah akan terungkap hukuman apa yang layak, pantas dan kompatibel terhadap pembunuhan yang telah dilakukan. Para hakim, sekali lagi hanya mengutip dalil-dalil agama yang bersifat umum tanpa ada keinginan untuk mengkajinya secara mendalam menurut kitab suci-kitab suci yang dijadikan landasan sumber hukumnya.

Memperhatikan beberapa argumentasi hukum Mejelis Hakim yang beberapa norma agama (transendental) sebagai bagian dari argumentasi hukumnya, secara umum, paradigma berfikir hukum transendal yang dilakukan oleh hakim sudah dapat dikatakan baik sebagai sebuah terobosan dan awal mula pembiasaan berargumentasi hukum dengan memperhatikan norma lain di luar norma hukum positif.

Namun argumentasi hukum yang diantaranya mengintrodusir norma hukum transendental dari Majelis Hakim terkesan hanya memilih dan memilah norma hukum hukum agama (transendental) yang bersifat umum. Dalam hal ini hanya memilih norma (diktum suci) agama (transendental) mengenai larangan perbuatan membunuh tanpa disertai dengan ancaman sanksi atas perbuatan yang dimaksud. Padahal di dalam Bibel (Injil), Weda, al-Qur'an dan Hadits terdapat banyak diktum-diktum suci yang menyebutkan sanksi atas kejahatan pembunuhan yang dilakukan baik secara sengaja maupun tidak sengaja. Adapun kasus yang dihadapi dapat dikategorikan sebagai perbuatan yang disengaja dengan argumentasi pelaku pembunuhan (terpidana) telah mempersiapkan dan membawa senjata tajam (golok) untuk digunakan sebagai alat menghilangkan nyawa orang bila perbuatan jahatnya diketahui oleh orang lain. Lebih dalam lagi, bahwa pembunuhan (penghilangan nyawa) mengakibatkan 2 (dua) korban meninggal dunia dan 1 (satu) korban terluka arah akibat perbuatan terdakwa.

Melihat pada fakta persidangan, tuntutan jaksa penuntut umum dan alasan untuk meringankan hukuman terhadap pelaku oleh kuasa hukum dan mempertimbangkan norma hukum positif diserta dengan argumentasi hukum dan non hukum lainnya, Majelis Hakim merumuskan perbuatan terdakwa sebagai perbuatan yang sesuai pasal 340 KUHP "Barangsiapa dengan sengaja dan dengan direncanakan lebih dahulu menghilangkan nyawa orang lain, dihukum karena pembunuhan direncanakan (moord), dengan hukuman mati atau penjara seumur hidup atau penjara sementara selama-lamanya dua puluh tahun" jo pasal 65 ayat (1) KUHP “dalam hal perbarengan beberapa perbuatan yang harus dipandang sebagai perbuatan yang berdiri sendiri sehingga merupakan beberapa kejahatan, yang diancam dengan pidana pokok yang sejenis, maka dijatuhkan hanya satu pidana" dan ketiga primair pasal 338 KUHP "barangsiapa dengan sengaja merampas nyawa orang lain, diancam karena pembunuhan dengan pidana penjara paling lama lima belas tahun" jo pasal 53 ayat (1) KUHP "mencoba melakukan kejahatan dipidana, jika niat untuk itu telah ternyata dan adanya permulaan pelaksanaan, dan tidak selesainya pelaksanaan itu, bukan semata-mata disebabkan karena kehendaknya sendiri.

Berdasarkan legalitas KUHP di atas, dalam perkara Adriawan bin Subarjo hakim menjatuhkan hukuman sebagaimana yang dituntut oleh Jaksa Penuntut Umum (JPU), maka dalam hal ini argumentasi hukum transendental dengan cara mengintrodusir norma agama sebagai bagian dari argumentasi hukum dalam putusan belum atau tidak berpengaruh apa-apa terhadap putusan yang dibuat oleh Majelis Hakim. 
Artinya argumentasi hukum transendental yang tertuang dalam Putusan Nomor: 61/Pid.B/2011/PN.Pwr. belum menuntun Majelis Hakim untuk menjatuhkan hukuman maksimal (hukuman mati) sebagaimana yang tertera dalam pasal $340 \mathrm{KUHP}$.

Dari pembahasan atas konten argumentasi hukum transendental Mejelis Hakim dalam Putusan Nomor: 61/Pid.B/2011/PN.Pwr, paradigma berfikir hukum transendenntal pada para hakim yang terlibat, pertama, baru sebatas argumentasi yang hanya menghiasai lembar-lembar putusan pengadilan saja, belum sampai pada adanya pengaruh yang cukup signifikan terhadap hasil akhir dari putusan hakim tersebut. Hal tersebut dapat dipahami karena Majelis Hakim dalam perkara ini hanya memilih dan memilah diktum suci yang bersifat umum terhadap larangan perbuatan pidana tanpa menyertakan sanksi hukum apa yang layak untuk perbuatan berupa kejahatan pembunuhan berencana, apa lagi korbannya lebih dari satu orang meninggal dunia.

Kedua, penyajian argumentasi hukum transendental berupa pengampunan terhadap perbuatan dosa yang ada dalam 4 (empat) diktum suci agama hanya sebatas sebagai pemberitahuan atau informasi saja kepada terdakwa untuk menerima hukuman, belum sampai pada upaya obyektifikasi terhadap diktum tersebut untuk aplikasinya dalam realitas hukum yang dihadapi.

Pengkajian paradigma transendental hukum justru terjadi pada daerah dimana hampir tidak ada kasus hukum yang menjadi sorotan berita nasional (PN Purworejo), walaupun begitu ini adalah awal yang menggembirakan untuk penyemaian hukum Indonesia yang transendentalis.

Paradigma berfikir hukum transendental yang tertuang dalam argumentasi hukum dalam putusan pengadilan ini, terjadi pada sebah Pengadilan Negeri Purworejo dengan klasifikasi 1B. Sedangkan telah menjadi maklum bahwa kelas pengadilan ini menunjukkan tidak begitu banyak persidangan yang dilakukan oleh PN Purworejo, walaupun secara kompetensi relatif, wilayah kekuasaan Kabupaten Purworejo cukup luas. Kiranya dominasi wilayah pedesan yang mayoritas dengan tipologi rural society yang guyub dan rukun menjadikan problematika atau sengketa hukum tidak begitu banyak ditangani oleh PN Purworejo. Dari sisi keragaman beragama, Islam mayoritas di seluruh wilayah kecamatan yang ada dalam Kabupaten Purworejo.

\section{Kesimpulan}

Hukum transendental merupakan salah satu paradigma berfikir hukum yang sedang dikembangkan oleh sebagian para pemikir hukum, khususnya di Indonesia, namun sesungguhnya aplikasi dalam realita hukum terkhusus dalam putusan pengadilan telah ada akarnya, contohnya adalah dalam argumentasi hukum yang tertera dalam putusan pengadilan dimana Bismar Siregar terlibat dalam penyusunannya. Dalam dasawarsa terakhir ini, argumentasi hukum transendental muncul kembali, khususnya dalam Putusan Nomor: 61/Pid.B/2011/PN.Pwr di Pengadilan Negeri Purworejo.

Kesimpulan dari tulisan ini adalah bahwa aplikasi paradigma hukum transendental mulai muncul lagi dalam penegakan hukum di Indonesia, dan adapun prospek masa depan hukum transendental dalam peradilan di Indonesia khususnya sangat terbuka, apalagi ditunjang oleh pewacanaan paradigma hukum transendental yang sedang ramai digalakkan pada perkembangan pemikiran hukum di Indonesia. Adapun dalam aplikasi atau penggunaan argumentasi hukum yang mengintrodusir paradigma hukum transendental khususnya dalam Putusan Nomor: 61/Pid.B/2011/PN.Pwr, Majelis Hakim dalam hal ini terkesan; a) hanya memilih dan memilah norma hukum transendental dari diktum kitab suci agama yang bersifat umum, enggan mengelaborasi lebih dalam dan luas terhadap diktum atau norma yang memuat sanksi hukum terhadap suatu tindak pidana (dalam hal ini pidana pembunuhan), b) norma hukum transendental yang digunakan sebagai argumentasi hukum belum dapat memberi warna secara signifikan terhadap putusan pengadilan, sehingga kesannya diktum dari kitab suci itu baru sekedar menjadi penambah argumentasi hukum dalam lembar-lembar putusan pengadilan. 


\section{Daftar Pustaka}

\section{Buku dan jurnal}

Abdullah Ahmed al-Na'im, 2001, Dekonstruksi Syari'ah: Wacana Kebebasan Sipil, Hak Asasi Manusia dan Hubungan Internasioanl dalam Islam, Yogyakarta: LkiS Pelangi Aksara.

Abraham S. Blumberg, 1970, Criminal Justice, Toronto: Burns and Mac Eachem Ltd.

Absori dkk, 2017, Transendensi Hukum Prospek dan Implementasi, Yogyakarta: Gentha Publishing.

Farkhani, 2014, Pengantar Ilmu Hukum Cetakan Keempat, Salatiga: STAIN Salatiga Press.

Farkhani dan Evi Aryani, 2016, Hukum dan Wajah Hakim dalam Dinamika Hukum Acara Peradilan, Surakarta: Pustaka Iltizam.

Feteris, E.T., 1994, Redelijkheid in Jurisdische Argumentatie, Een Overzicht van Theorieen Over Het Rechtvaardigen van Juridische Beslissingen, W.E.J. Tjeenk Willink, Zwolle.

Herlien Budiono, 2006, Asas Keseimbangan bagi Hukum Perjanjian Indonesia, Hukum Perjanjian Berlandaskan Asas-Asas Wigati Indonesia, Bandung: P.T. Citra Aditya Bakti

Komisi Yudisial, 2014, Kualitas Hakim dalam Putusan, Jakarta: Sekretaris Jenderal Komisi Yudisial Republik Indonesia.

Kuntowijoyo, 2006, Islam Sebagai Ilmu: Epistimologi, Metodologi dan Etika, Yogyakarta: Tiara Wacana.

Martin P. Golding, 1984, Legal Reasoning, New York: Alfreda A. Knoff Inc.

Otje Salman, 2012, Filsafat Hukum (Perkembangan dan Dinamika Masalah), Bandung: Refika Aditama.

Sondang P. Siagian, 1991, Organisasi, Kepemimpinan dan Perilaku Administrasi, Jakarta: Gunung Agung.

T. Arroba,1998, "Decision Making by Chinese -US", Journal of Social Psychology. Vol. 38.Theo Huijbers, 1982, Filsafat Hukum dalam Lintasan Sejarah, Yogyakarta: Kanisius.

\section{Situs Internet}

www.pt-bandung.go.id, diakses pada tanggal 28 Agustus 2017

\section{Perundang-Undangan}

Undang-Undang No. 48 tahun 2009 tentang Kekuasaan Kehakiman

Undang-Undang No. 49 tahun 2009 tentang Peradilan Umum, 